\title{
Research of Posibilities for Implementation of Innovations in Advanced Systems for Biomass and Other Solid Waste Treatment
}

\author{
RADOLJUB P. TOMIĆ, Faculty for Strategic \\ and Operational Management, Belgrade \\ MILAN Ž. RADOSAVLJEVIĆ, Faculty for Strategic \\ and Operational Management, Belgrade \\ LARISA N. JOVANOVIĆ, ALFA University, Belgrade
}

\author{
Previous announcement \\ UDC:628.4.043:005 \\ DOI:10.5937/tehnika1506059T
}

In the start, an aproach of the situation regarding the objectification of innovation is given (from the level of invention and patents), through design to commercialization of new products (development and manufacturing) in accordance with advanced research and correct implementation of technological innovations.

It shows the aspects of the integral system of industrial and municipal waste (there are biomass after the landscaping, green areas and parks), in the process of industrial production and processes which comprise the municipal utilities with waste treatments.

Some of crucial elements of environmental policy and environmental objectives are emphasised. An algorithm of the activities of the work process regarding the management of solid waste-valuable raw material is given.

It was pointed out that waste management is carried out, according to the requirements of legislation and the specifics of functioning of public enterprises and companies (including SMEs).

Outputs are related to the development and implementation of systems for the treatment of solid waste (wood, biomass, industrial solid waste).

Key words: environmental policy, waste management, innovation, biomass, wood waste, industrial solid waste, waste treatment

\section{INTRODUCTION}

The concept of Integrated Sustainable Solid Waste Management (ISSWM) is based on the principles of sustainable development. This concept emphasizes the role that the participants in the accumulation of waste (waste generators and collectors - companies, households, agricultural farms, etc.) have in waste manipulation ISSWM includes practical and technical elements of the system of waste management, which includes minimization, prevention, collection, separation, recycling and reuse. Integrated Solid Waste Management is a concept and an analytical framework that deals with aspects that are often neglected in the management of waste. ISSWM link institutional, social, technical and financial aspects, and thereby highlights the

Author's address: Radoljub Tomić, Faculty for Strategic and Operational Management, Belgrade, Staro Sajmište 29

Paper received: 13.11.2015.

Paper accepted: 01.12.2015. important role of various participants in waste management and in operations from the waste collection to the treatment. This way to approach the problem is important because the long-standing gaps in the treatment of waste in our country related to inadequate analysis of the problem, which led to the extraordinary accumulation of issues with waste management [1].

Integral sustainable solid waste management improves the previous concepts of waste management, where the technology was treated as the most important and which lead to negative experiences. It provides insight into the less obvious but equally urgent aspects of planning, including legal, political, institutional, socio-cultural and environmental aspects. Integrated waste management can have adverse effects on human health, the environment, and natural resources. Planning of integrated waste management should include the prevention of waste (minimizing the production of waste materials) and the recycling of waste. It is necessary to introduce new methods of waste treatment. 
Renewable energy sources, such as biomass and biogas from agriculture, can help improve the competitiveness of industries and have a positive impact on regional development and employment $[2,3]$.

The European renewable energy industry has already reached an annual turnover of $€ 10$ billion and employs 200,000 people. Europe is the global leader and the front runner in renewable energy technologies.

Adequate treatment of solid waste is important to human health but because of the additional political and economic reasons, as well as a significant impact on the quality of the environment, it deserves greater attention of local authorities. The European Union and various institutions provide financial assistance for waste management projects in the candidate countries, such as the IPSA instruments of the European Union. In developing strategies for the waste management, candidate countries have to consider the sources of funding [4]. For that reason it is important to shift to renewable energy sources, such as biomass. Biomass includes a variety of raw materials, products, byproducts and waste materials which come from forestry, agriculture, and communal solid waste.

It is obvious that Serbia does not achieve satisfactory results in scientific-research and innovation activities as evidenced by the modest results at the level of realization of new appeared solutions (products, technologies, processes, equipment, industrial software, services). There are however some positive examples, one of which includes realized solutions and appropriate decisions regarding the recognition of the status of "technical solution", Figure 1, within the innovation project which was founded as IP-34, in accordance with [5].

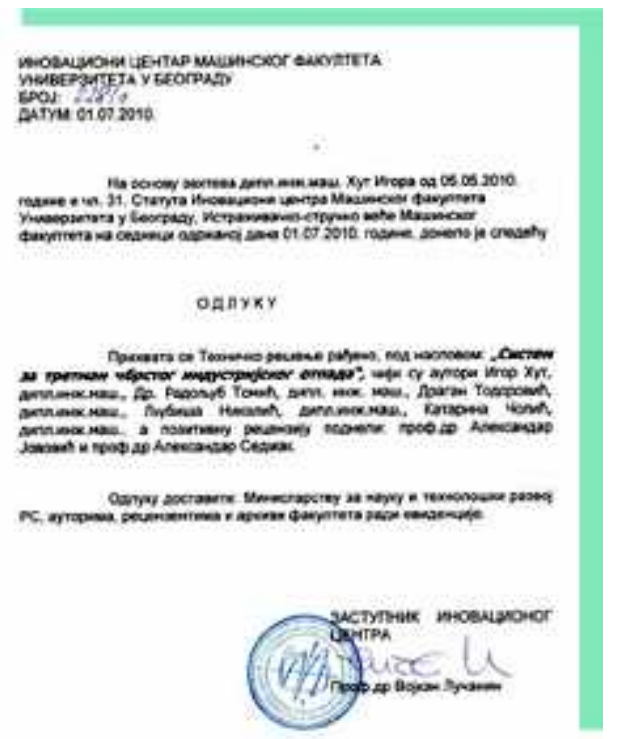

Figure 1 - Decision by IC MF Belgrade on recognition of achievements at the level of "Technical solution", within the innovation project IP-34
Achieved goals are also with recognizably positive results in related research project EE-243005A, in accordance with [6].

Coupling universities, SROs and IOs to the economy is at an unacceptably low level, and because of that need serious work to improve cooperation between all entities at different levels and at various fields contribute to the strengthening of the domestic economy. It is concern for the progress of the integrated process of research from inventions to the innovations, according with technical-technological and market trends, and through the implementation of various projects of interest for the development of stakeholders and participants in their realization with focus at the development of the region, Serbia and countries in the region, through which will allow raising the level of competitiveness of the wider region and approaching the level of development of advanced EU countries.

In connection with the foregoing, it is important to establish a system of support for the essential work of the university, SROs and IOs, as a rule, with the strengthening of international cooperation on research and innovation projects to be funded from different fonts the EU / EC, as FP6, FP7, H2020 and IPA/, discussed in more detail in [11].

Our faculties and institutes must be seriously dedicated to this business with respect for the relevant challenges and with mandatory international cooperation (initially with: Italy, Slovenia, Croatia, Bosnia, Greece, Cyprus, Portugal, Spain).

Systemic measures adopted by the Government of Serbia, which directly articulates the Ministry of Education, Science and Technological Development, should contribute to strengthening university-economic cooperation with the approaches towards the ambitious implementation of SRD results in SMEs (here, SCA has the vital role in creating the ambient and connecting to the corresponding operators).

How do we translate the results from faculties and institutes achievements to the level of technological applications in the economy is also one of the key issues. Noting the important role of the IPO, in terms of taking care of intellectual property and the treatment of patents containing more ambitious solutions in relation to the relevant prior art and have the potential to get through their realization achieve reliable and commercially viable solutions of new products and services.

Logistics is essential at all levels of research, development, design, implementation, delivery and aftersales support. The probability that a project will be carried out and completed within planed activities and resources must be with established suitable methods and models for risk assessment, especially in the 
preparatory phase (the phase of implementation means the models relating to the risk management).

The content of this paper is based on the established and generally accepted principles, achievements, and research and development and innovation assumptions with realistic aspirations in the field of normative-legal regulation, organization, management and technology, quality, ecology, energy and economy [5-7].

\section{IDENTIFICATION OF THE ISSUES REGARDING TO THE TREATMENT OF TYPICAL TYPES OF SOLID WASTE}

We are aware of the general technological and industrial backwardness of Serbia compared to Europe and the developed world, but in the same sense highlights and completely unjustified technological backwardness regarding the use of significant quantities of various wastes, which, with appropriate treatment can be converted, for example, into a suitable power supplies, which is a real resource for improving the energy balance of the country.

During the work on the problems of this category, we found that a lot of attention paid to the collection of data and information on the level of recommendations, directives, standards and norms, through various types of reports (unclear whether they are still in a purposeful use or is it at the level of mere statistics and saving existence of the body, associations and organizations and their employees) to different platforms, policies and other documents.

In the all of the aforementioned are present in very small contributions to specific embodiments by the management at all levels (from state to local community) as well as the inclusion of individual farms and households in the energy system of the country, whether it is savings (for example, at the level of replacing conventional fuels in public utilities-power stations, etc.) or in the production and sale of energy (e.g., the delivery of electricity through wind power generators with stabilized parameters of voltage and frequency, etc.).

Our research, directly realized within "Prva petoletka - S\&R" JSC, Trstenik has been focused on the development of systems, machines and equipment for the treatment of various types of materials and waste in the field of renewable energy sources (based fuels from biomass from agricultural production or on the basis of algae and based fuels from suitable raw materials in the field of wood, paper, other industrial and municipal waste etc.), always with environmental protection (regarding the elimination or reduction of air pollution, water pollution and soil), as pointed out in [8-10].
In this paper, the basic morphology, structure and function of the system (main subsystem is the hydraulic press) for the treatment of biomass and wood (can be forest waste or waste in the industrial production), according to $[9,10,13]$. Corresponded considerations also are conducted in [10-12].

Basically, this is a modest but distinctive contribution to solving the problems and giving results, clearly present an important global issue in the area of energy efficiency and environmental protection. The results will be illustrated on one particular model, but based on the same achievement can be extrapolated for the solution of different systems, machines and equipment for the treatment of specific groups of materials and for the needs of different users (from the internal use of energy - straw bales or paper) to the external market supply (e.g. briquettes with different geometric shapes, also with different characteristics and quality at energy and environmental).

Project EE-243005, in the content of research as a key consideration envisages the definition of the concept of the program for the use of certain types of waste wood and biomass as energy sources in the function of the minimum cost at the level of urban areas. In the present context, we examine the characteristics of untreated raw-materials (physical, chemical, mechanical, technical, technological, energy and environmental) and perform analyzes the opportunities for appropriate treatments in reducing moisture content and dimensions of materials, the creation of facilities for its storage and handling, and improvement of its energy characteristics after squeezing (baling and / or briquetting).

Industrial wood waste (industrial waste, used for packaging, boxes, containers and pallets) and municipal wood waste (after preparing of the avenue, arrangement of riverbanks, waste from cemeteries, etc.) is prepared into solid waste. Biomass at the level of municipal waste (grass from lawns, parks and playgrounds, as well as fallen leaves, leaves and branches after processing urban trees felled finely vegetation, shrubs, etc.) is also going into the solid waste. For both types of waste can implement procedures for resolving identified problems of solid waste, as in the case of the set of ordered activities and documents of solid industrial waste.

Practically, due to the raw materials that are necessarily compressed-treated (baled, briquetted) is essential good industrial application procedures, as the already is exposed in [9]. Globally, on all procedural levels (manipulating and technological) we need the right equipment (upgrading existing machines, vehicles and equipment or specialized equipment for waste treatment). For example, for the production, handling 
and transport of waste there are adequate utility vehicles, as well as general purpose vehicles with the necessary superstructure (mechanical, electrical, hydraulic and pneumatic). For the treatment of collected raw sewage there are proper lines and process equipment which supporting activities defined in Figure 2.

\section{GENERAL OVERVIEW OF HYDRAULIC SYSTEM (BALING AND BRIQUETTING OF BIOMASS AS SOLID WASTE)}

Practically, one of the special and the most important items is certainly hydraulic press, along with associated equipment for the preparation of the input waste material: to dry mass (or rather to put a weight on the appropriate level of humidity, practically from $14-18 \%$ ), for the providing of quantity and geometrical characteristics of the input waste (granulation), including the elimination of metal objects, stones and the like.

With regard to our considerations, it turned out that the prospects to representative quantity of municipal waste could have exceeded the performance given in Figure 3.

Modules, for the preparation of waste wood and biomass for entry into treatment processes, certainly are different. For that will not be discussed here, since this matter to a significant extent have to deal with experts from thermodynamics.

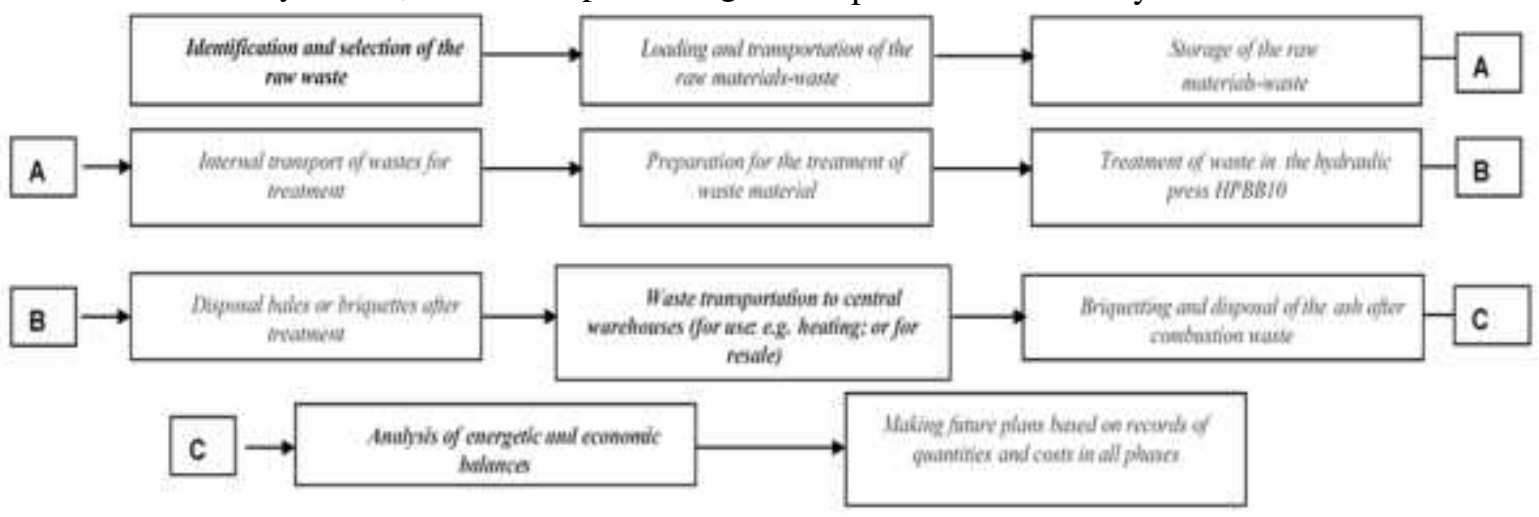

Figure 2 - Scheme of solid waste treatment

If it turns out the need for treatment of larger quantities and higher security dynamics bales and briquettes, as a potential fuel, it is possible, based on the products made in IHP PPT (directly programs "PPTHydraulics" JSC, Trstenik), to develop a lot of very different useful and rational solutions [5].

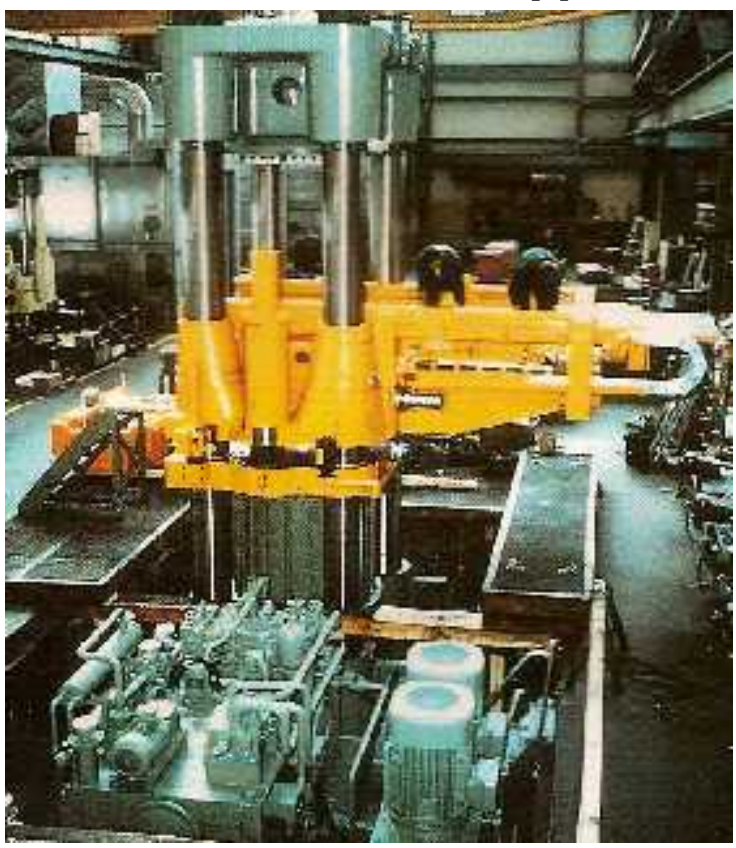

Figure 3 - Press HPBB10 for the treatment
Equipment of the considered systems (hydraulic presses for baling and briquetting biomass and solid waste wood - HPBB10) is shown in Figure 3. The characteristics of the hydraulic press - HPBB10, in Fig. 3 , are given in [6]. An illustration of the process of briquetting is given in Figure 4.

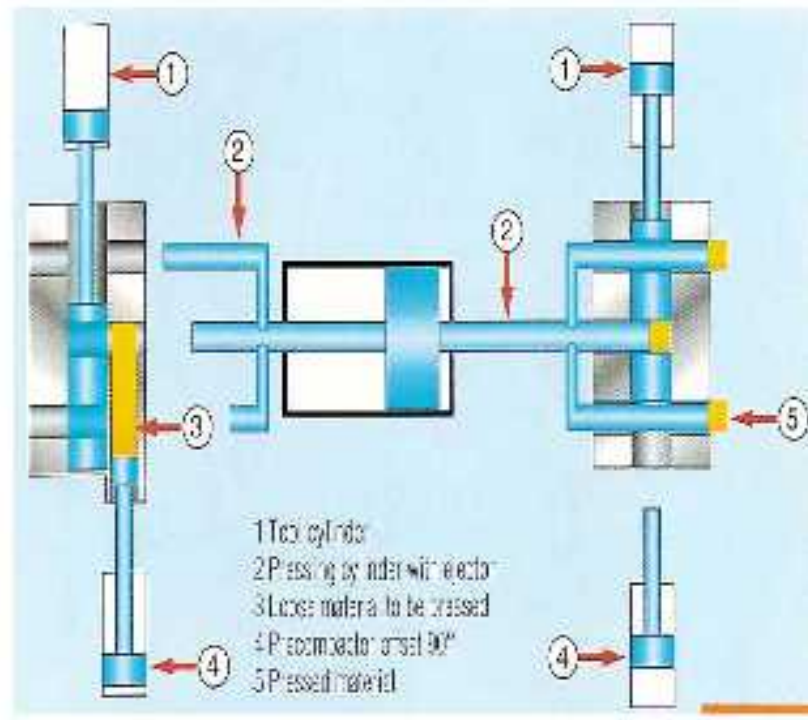

Figure 4 - Schematic illustration of the process of solid waste (general appearance) being made in the press for briquetting 

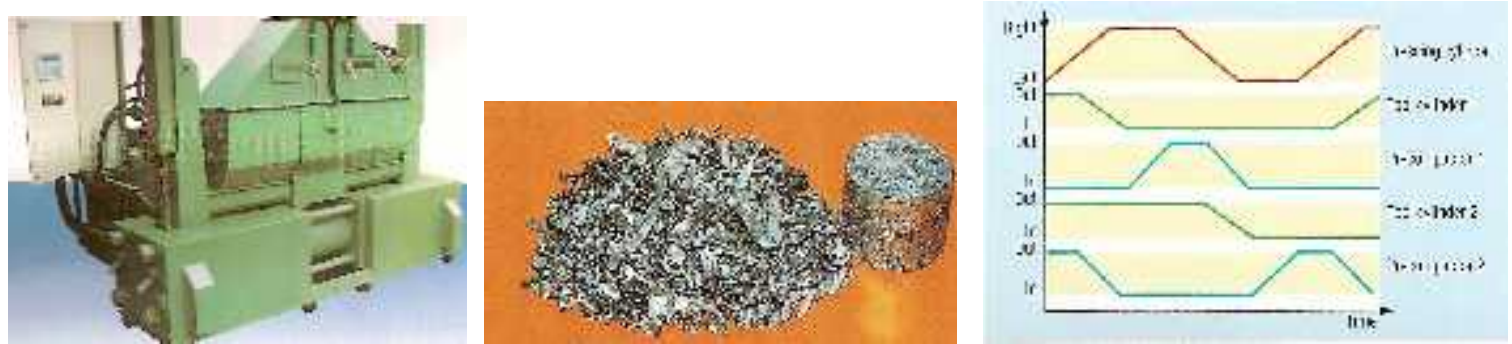

Figure 5 - Briquetting presses a) general appearance presses; $b$ ) material intended for extrusion and molding c) block diagram of the work of presses

One press for briquetting with the corresponding waste is given in Figure 5, and characteristics also are given in [6]

\section{CONCLUSION}

The present installed and analyzed problem and its partial removal (in the area of capacity development, machines and equipment in the field of treatment of biomass and solid wood waste as possible material for suitable energy) can be used in both development and production purposes. The compatible suppliers of components, devices and subsystems (concerned to the equipment as well as for educational purposes), young researchers, associates and students, will definitely have to seriously deal with the problem because the life all of that needs to include.

The young professionals will become more and more aware of the presented problems and the need to solve them, as opposed to the current presence of typical categories of researchers, engineers and experts, who have had primarily upgrading with the technical and technological development of products and technologies in the past few decades.

Everything what we said, is necessary should to lead to higher levels of development of business systems, production of reliable technical and market products with a high level of repeatability quality of serial units, etc.

In this area, it could be expected good results of energy efficiency and environmental protection in the Republic of Serbia (without the above mentioned results nothing serious can be done).

Of course, it must be noted that, we hope that our teaching, scientific and research and development system, in real economic terms could be with usefulness (what current generations of experts do not have, in part because of the poverty of the country and partly because of miss-allocation of investments and funds) to produce a greater number of future experts, high business ethics, who will be the authors of the future advanced solutions and who will have even more pragmatism and more conveniences to work, giving to the local economy, energy and environmental protection

ambitious solutions for the common good and generating the preconditions for the progress of our country.

Development of process equipment for solving various problems in the field of treatment of waste and energy utilization of non-conventional fuels and related materials, must be given special attention, and there are realistic imposes of needs for the development, production and placement of new advanced products, with the involvement of suitable industrial capabilities, what exist within the renowned business and industrial system as IHP "Prva petoletka" JSC, Trstenik.

\section{REFERENCES}

[1] Jordačijević S, Jovanović L, Radosavljević Ž, Anđlković M, Koncept integralnog održivog upravljanja otpadom, Ecologica 58, 237-244, 2010.

[2] Golušin M, Dodić S, Vučurović D, Ostojić A, Jovanović L, Exploitation of biogas power plant - CDM Project, Vizelj, Serbia, Journal of Renewable and Sustainable Energy 3, 052701, pp. 1-11, doi: 10.1063/1.3631820, 2011.

[3] Golušin M, Dodić S, Vučurović D, Jovanovic L, Munitlak Ivanović $\mathrm{O}$, Sustainable energy management in industry of Republic of Serbia. Biogas power plants advantages, Industrija 40, No 4, 107-124, 2012.

[4] Đuran J, Golušin M, Munitlak Ivanović O, Jovanović L, Andrejević A, Renewable energy and socioeconomic development in the EU, Problemy Ekorozwoju 8, No 1, 105-114, 2013.

[5] Tomic R, Todorović D, Hut I, Nikolić Lj, Development of systems for the treatment of hard industrial waste (Razvoj sistema za tretman čvrstog industrijskog otpada; founded by MSTD Serbia, Innovation Project No. 451-01-00065/2008-01/34), Belgrade-Trstenik, 2008-2010.

[6] Ćurčić S, Ječmenica R, Djurić M, Tomić R, Development and implementation of logistics systems for the use of biomass and waste wood as fuel in households and industry (Razvoj i primena logističkih sistema za korišćenje biomasa i otpadnog drveta kao energenta u domaćinstvima $\mathrm{i}$ industriji; founded by 
MSTD Serbia, EE-243005A), Čačak-Trstenik, 20062009.

[7] Tomić R, Petakovic V, Arsic M, Importance of development of innovative activities - An overview of the identification of intellectual property and its treatment, from patents to their commercialization products and services, "Application of New Technologies in Management", ANTIM-2014, ISBN 97886-87333-42-0 (FSOM \& FORKUP), Zbornici radova COBISS.SR-ID, Zbornik radova -Volume 3, str.1041-1050 Belgrade, 24-26.april, 2014.

[8] Tomić R, Review and status of domestic development of quality control systems in accordance to JUS ISO 9000 (Prilog objektivizaciji domaćih dostignuća u vezi sistema kvaliteta prema JUS ISO 9000), $5^{\text {th }}$ Conference "Dependability and quality management", Belgrade, p.267-273, 2002.

[9] Radovanović M, Krkić M, Tomić R, New instruments and protection wood procedure development and application with creoste oil, $2^{\text {nd }}$ International Conference "Research and development in mechanical industry-RaDMI 2002", Vrnjacka Banja, p. 1050-1054, 2002.
[10]Milovanović B, Stanković V, Nedeljković V, Tomić $\mathrm{R}$, The development of microwave applicator for drying materials (Razvoj mikrotalasnih aplikatora za sušenje materijala; founded by MSTD Serbia, EE0085), Nis-Trstenik, 2003-4.

[11]Nedeljković V, Tomić R, Contribution to improving the treatment of industrial waste in terms of environmental protection (Prilog unapređenju tretmana industrijskog otpada sa aspekta zaštite životne sredine), International Conference: ELECTRA IV, p. 419-424, Tara, 2006.

[12]Ćuk M, Arnaldo K, Tomić R, Study of the possible equipment and preparation of the fuel for substitute electricity for heating (internal document); Studija moguće opreme i pripreme goriva radi supstitucije električne energije za grejanje (interni dokument), Jagodina-Trstenik, 2006.

[13]General external and internal documentation: standards, norms, directives, manuals, brochures, catalogs (Opšta eksterna i interna domumentacija: standardi, norme, direktive, prirucnici, prospekti, katalozi), Trstenik, 2015.

\section{SUMMARY}

\section{ISTRAŽIVANJE MOGUĆNOSTI ZA PRIMENU INOVACIJA U NAPREDNIM SISTEMIMA ZA PRERADU BIOMASE I DRUGIH VRSTA ČVRSTOG OTPADA}

Prvo je predstavljena situacija u vezi sa objektivizacijom inovacija (od nivoa pronalaska do patenta), od projektovanja do komercijalizacije novih proizvoda (razvoj i proizvodnja) u skladu s naprednim istraživanjima i pravilnim implementacijama tehnoloških inovacija.

Prikazani su aspekti integralnog sistema upravljanja industrijskim $i$ komunalnim otpadom (biomasa nakon uređenja zelenih površina i parkova), u procesu industrijske proizvodnje i procesima koji uključuju tretmane otpada u komunalnim preduzećima.

Naglašeni su neki od ključnih elemenata politike zaštite životne sredine i ekoloških ciljeva. Prikazan je algoritam aktivnosti u procesu rada u pogledu upravljanja čvrstim otpadom kao vrednom sirovinom.

Istaknuto je da se upravljanje otpadom vrši u skladu sa zahtevima zakona i specifičnostima funkcionisanja javnih preduzeća i kompanija (uključujući mala i srednja preduzeća).

Ishodi su usmereni na razvoj i implementaciju sistema za tretman čvrstog otpada (drveta, biomase, čvrstog industrijskog otpada).

Ključne reči: ekološka politika, upravljanje otpadom, inovaciji, biomasa, otpad u šumarstvu, industrijski čvrsti otpad, tretman otpada 